\title{
Bovine $\beta$-casein: Detection of two single nucleotide polymorphisms by bidirectional allele specific polymerase chain reaction (BAS-PCR) and monitoring of their variation
}

\author{
Stefania Chessa ${ }^{1}$, Omar Bulgari $^{2}$, Attilio Rossoni $^{3}$, Gabriella Ceriotti $^{4}$, Anna Maria Caroli $^{2^{\star}}$ \\ ${ }^{1}$ IBBA-CNR, Milano, Italy \\ ${ }^{2}$ Department of Molecular and Translational Medicine, University of Brescia, Brescia, Italy; \\ *Corresponding Author: caroli@med.unibs.it \\ ${ }^{3}$ Italian Brown Breeders Association, Bussolengo, Italy \\ ${ }^{4}$ Department of Veterinary Science and Technology for Food Safety, University of Milan, Milan, Italy
}

Received 2 October 2012; revised 16 November 2012; accepted 26 November 2012

\begin{abstract}
Due to the functional importance of bovine milk protein polymorphisms, their correct discrimination is of great interest both from a scientific and practical point of view. Nowadays a large number of commercial platforms are available for semi-automated or fully automated SNP genotyping. However, in some cases the use of simple and rather cheap methods is an effective tool to be implemented within one's own laboratory for the routine analysis of a specific SNP. The present paper describes two simple tests based on the bidirectional allele-specific polymerase chain reaction (BAS-PCR) developed for the identification of $\beta$-casein (CSN2) $B$ and $I$ genetic variants. The practical application of the two methods on a panel of $\mathbf{8 4}$ Italian Brown bulls and 100 Italian Friesian cows is also discussed, including the biological significance of the two genetic variants and the importance of taking their occurrence into account when linkage analyses are performed on milk functional properties. A combined system for analysing milk protein variants by isoelectrofocusing (IEF) and the BASPCR assay developed for CSN2*I is described.
\end{abstract}

Keywords: Bovine $\beta$-Casein; Milk Protein Polymorphism

\section{INTRODUCTION}

Ruminant's caseins $\left(\alpha_{\mathrm{S} 1}\right.$-casein, $\beta$-casein, $\alpha_{\mathrm{S} 2}$-casein, $\kappa$-casein) are respectively coded by $C S N 1 S 1, C S N 2$, $C S N 1 S 2$ and $C S N 3$ genes which are highly polymorphic in cattle. Some genetic variants were found to be associated with peculiar biochemical properties affecting animal breeding and human nutrition [1].

Up to $45 \%$ of bovine milk casein $(\mathrm{CN})$ is constituted by the $\beta$-CN, which consists of a single chain of 209 amino acids [2]. A total of 12 genetic variants involving at least 13 amino acid exchanges were described in cattle [1]. In all breeds, the most common variants are $C S N 2 * A^{1}$ and $\operatorname{CSN} 2 * A^{2}$, followed by the $\operatorname{CSN} 2 * B$, which occurs at higher frequencies in some breeds, i.e. Normande and Jersey (frequency range: 0.30 - 0.45), Montbéliarde, Italian Brown, Reggiana, Modenese and Italian Red Pied (frequency range: $0.10-0.25$ ) [3]. The most recently identified $C S N 2 * I$ variant is rather common in Italian Holstein Friesian (frequency $=0.12$ ) and Red Pied (frequency $=0.14$ ) [4], and in Dutsch Holstein Friesian (frequency $=0.19)[5]$.

Milk protein polymorphisms can be identified at the protein level analysing individual milk samples by biochemical techniques like electrophoresis [6], isoelectrofocusing (IEF) [7-9] or high performance liquid chromatography [10]. In particular, IEF methods allow to identify 31 of the 45 variants detected in Bos taurus; 23 of them are not rare variants [1].

The investigation at the DNA level allows to detect milk protein genetic polymorphisms also in animals not presenting the gene product (males, non-lactating females) as well as mutations in the non-coding regions of the genes [11]. Bidirectional allele-specific polymerase chain reaction (BAS-PCR) [12], amplification created restriction sites [13], multiplex PCR-single strand conformational polymorphism [14] were already applied to CSN2 analysis, as well as the most recent development of high-throughput assays which allow the simultaneous detection of several SNP $[15,16]$. 
Nowadays a large number of commercial platforms are available for semi-automated or fully automated SNP genotyping, differing in SNP selection, reaction chemistry, signal detection, throughput, cost, and assay flexibility. However, conventional methods can be implemented within one's own laboratory if specific attention is given to a particular SNP.

The present paper describes a BAS-PCR assay implemented in order to test a sample of Italian Brown bulls of known genotypes for the most important milk protein variants, but untyped for the specific SNP associated to $C S N 2 * B$ variant. Similarly an original BAS-PCR assay was developed to identify at the DNA level CSN2*I which cannot be distinguished when milk protein variants are analysed by IEF because the amino acid exchange Met to Leu at position 93 of the mature protein does not affect the protein isoelectric point [4].

\section{MATERIALS AND METHODS}

Two separate BAS-PCR tests were implemented for the analysis of two specific CSN2 SNP, namely $\mathrm{G}_{8267}$ vS $\mathrm{C}_{8267}$ and $\mathrm{C}_{8178}$ vs $\mathrm{A}_{8178}$ (nucleotide position referred to GenBank No. X14711) which differentiate $C S N 2 * B$ vs $C S N 2 * A^{1}$ (and all the other CSN2 alleles), and CSN2*I vs $\operatorname{CSN} 2 * A^{2}$ (and all the other alleles except the rare $C S N 2 * H^{2}$ ) respectively [1].

\subsection{CSN2*B BAS-PCR Detection}

For the identification of $C S N 2 * B$, the BAS-PCR described by G. Damiani et al. [12] was modified according to the laboratory needs. Different primers were designed from the reference sequence of bovine $\beta$-casein (GenBank No. X17411) using Primer 3 software [17], and different multiplex PCR (mPCR) conditions were used. The optimized mPCR was performed in a $50 \mu \mathrm{L}$ reaction mixture containing $2.5 \mu \mathrm{L}$ of DNA solution (25 to 100 ng), $1 \times$ AccuPrime $^{\mathrm{TM}}$ PCR Buffer II and $1 \mathrm{U}$ AccuPrime $^{\mathrm{TM}}$ Taq DNA Polymerase High Fidelity (Invitrogen, Foster City, California, USA) and the following primers: 400 nM of B External Forward (5'-AGT GGG TTA ATG AGA AAT CCT TC-3'), $60 \mathrm{nM}$ of B Internal Forward (5'-CCA GTT GAG CCC TTT ACT GAA AGC-3'), 100 nM of B Internal Reverse (5'-CAG TGA GAG TCA GGC TCT GC-3'), 300 nM of B External Reverse (5'-TAA TAG GGA AGG GTC CCC G-3'). The highlighted nucleotide within B Internal Forward and B Internal Reverse represents the SNP to be identified. Primers B Internal Reverse and B Internal Forward are specific for $C S N 2 * B$ and "non- $B$ " alleles, respectively (Figure 1).

The following conditions were used for the MPCR assay: an initial denaturation step of $94^{\circ} \mathrm{C}$ for $2 \mathrm{~min}$, followed by 35 cycles of $94^{\circ} \mathrm{C}$ for $30 \mathrm{~s}, 55^{\circ} \mathrm{C}$ for $30 \mathrm{~s}, 68^{\circ} \mathrm{C}$ for $30 \mathrm{~s}$, and by a final extension step of $68^{\circ} \mathrm{C}$ for $5 \mathrm{~min}$, using a Mastercycler Gradient ${ }^{\circledR}$ Thermal Cycler (Eppendorf, Hamburg, Germany). The mPCR products were analyzed by electrophoresis in $1.5 \%$ agarose gel and stained with SYBR ${ }^{\circledR}$ Safe DNA Gel Stain (Invitrogen, Foster City, California, USA) followed by image analysis with Dyversity High Resolution 2D Gel and Blot Imaging System (Syngene, Cambridge, UK). The efficiency of this staining method was compared with conventional ethidium bromide staining.

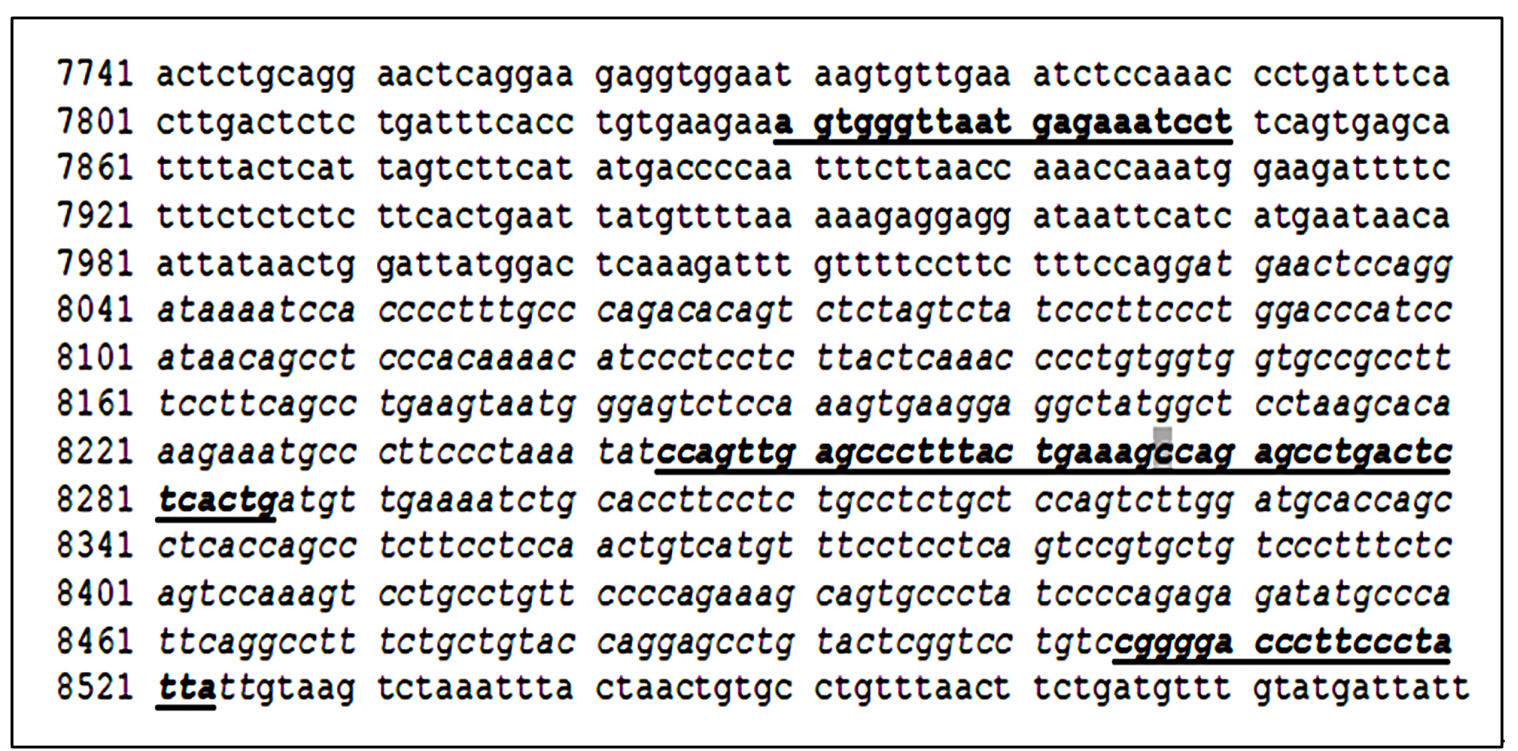

Figure 1. Detail of $C S N 2$ sequence GenBank No. X14711. Primers used for $C S N 2 * B$ detection are underlined and bolded. The two internal primers share the SNP (highlighted in grey) differentiating non-B (SNP $=$ C8267) and B (SNP $=$ G8267) alleles. Exon 7 is shown in italics. 


\subsection{CSN2*I BAS-PCR Detection}

A new BAS-PCR protocol was developed for the identification of $C S N 2 * I$. The optimized mPCR was performed in a $25 \mu \mathrm{L}$ reaction mixture containing $1.5 \mu \mathrm{L}$ of DNA solution (25 to $100 \mathrm{ng}$ ), $1 \times$ AccuPrime $^{\mathrm{TM}}$ PCR Buffer II and 1U AccuPrime ${ }^{\mathrm{TM}}$ Taq DNA Polymerase High Fidelity (Invitrogen, Foster City, California, USA) and the following primers: $400 \mathrm{nM}$ of $I$ External Forward (5'-tgc agg aac tca gga aga gg-3'), $160 \mathrm{nM}$ of $I$ Internal Forward (5'-cct ttc ctt cag cct gaa gta a-3'), $320 \mathrm{nM}$ of $I$ Internal Reverse (5'-cct tca ctt tgg aga ctc cca g-3'), 240 $\mathrm{nM}$ of $I$ External Reverse (5'-gat agg gca ctg ctt tct gg-3'). The highlighted nucleotide within $I$ Internal Forward and $I$ Internal Reverse represents the SNP to be identified. Primers $I$ Internal Reverse and $I$ Internal Forward are specific for $C S N 2 * I$ and "non- $I$ " alleles, respectively (Figure 2).

The following conditions were used for the mPCR assay: an initial denaturation step of $94^{\circ} \mathrm{C}$ for $2 \mathrm{~min}$, followed by 35 cycles of $94^{\circ} \mathrm{C}$ for $30 \mathrm{~s}, 56^{\circ} \mathrm{C}$ for $30 \mathrm{~s}, 68^{\circ} \mathrm{C}$ for $30 \mathrm{~s}$, and by a final extension step of $68^{\circ} \mathrm{C}$ for $5 \mathrm{~min}$, using a DNAEngine Peltier Thermal Cycler (Bio-RAD, Milan, Italy). Agarose electrophoresis and staining was performed as described for $C S N 2 * B$ BAS-PCR.

\subsection{Validation and Routine Analyses}

Both assays were set-up and validated analysing a panel of 20 DNA samples of known genotypes. Moreover, 84 Italian Brown bulls and 100 Italian Friesian cows were routinely analysed for $C S N 2 * B$ and $C S N 2 * I$, respectively, by the implemented protocols. DNA was extracted with DNeasy ${ }^{\circledR}$ Blood \& Tissue Kit (QIAGEN Gmbh, Hilden, Germany) from the bulls' semen and the cow's milk, respectively. Individual milk samples of the Italian Friesian cows were also typed by IEF [9] which allows the simultaneous detection of the most common milk protein variants.

\section{RESULTS AND DISCUSSION}

\subsection{BAS-PCR Assays}

The two BAS-PCR assays allowed a clear identification of the two SNP (Figures 3 and 4).

The amplification products obtained by $C S N 2 * B$ BASPCR were a common 694 bp fragment originated from B External Forward and Reverse primers, a $280 \mathrm{bp}$ fragment specific for all "non- $B$ " variants originated from $\mathrm{B}$ Internal Forward and B External Reverse primers, and a $457 \mathrm{bp}$ fragment specific for B variant originated from B External Forward and B Internal Reverse primers (Figure 3).

The amplification products obtained by $C S N 2 * I$ BASPCR were a common 698 bp fragment originated from I External Forward and Reverse primers, a 286 bp fragment specific for "non- $I$ " variants originated from $I$ Internal Forward and I External Reverse primers, and a 455 bp fragment specific for $I$ variant originated from $I \mathrm{Ex}-$ ternal Forward and $I$ Internal Reverse primers Ex7-EsF and Ex7-I. The common 698 bp fragment was clearly visible using only external primers, whereas if they are used with the internal primers their PCR product is almost completely used for amplification of the specific bands thus acting for nested-PCR (Figure 4).

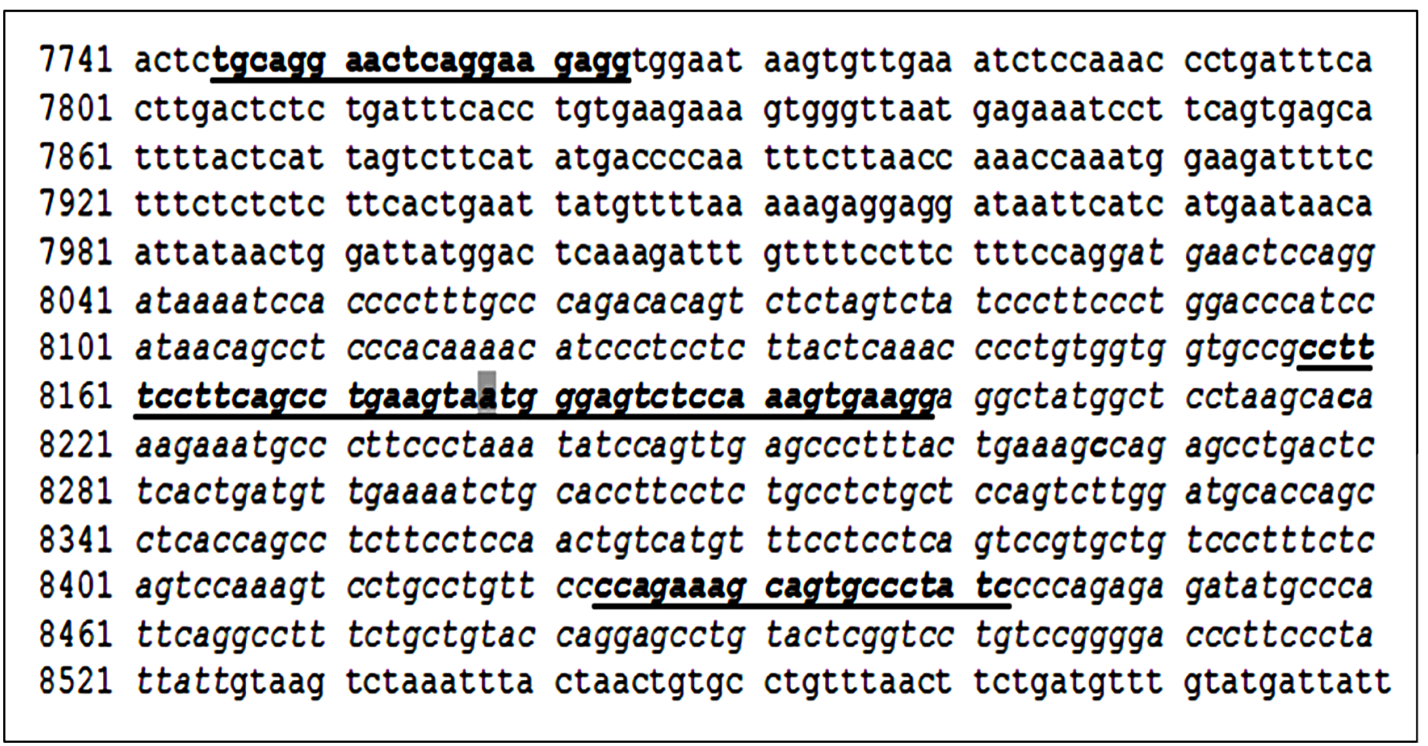

Figure 2. Detail of CSN2 sequence GenBank No. X14711. Primers used for $C S N 2 * I$ detection are underlined and bolded. The two internal primers share the SNP (highlighted in grey) differentiating non-I $\left(\mathrm{SNP}=\mathrm{A}_{8178}\right)$ and $I\left(\mathrm{SNP}=\mathrm{C}_{8178}\right)$ alleles. Exon 7 is shown in italics. 


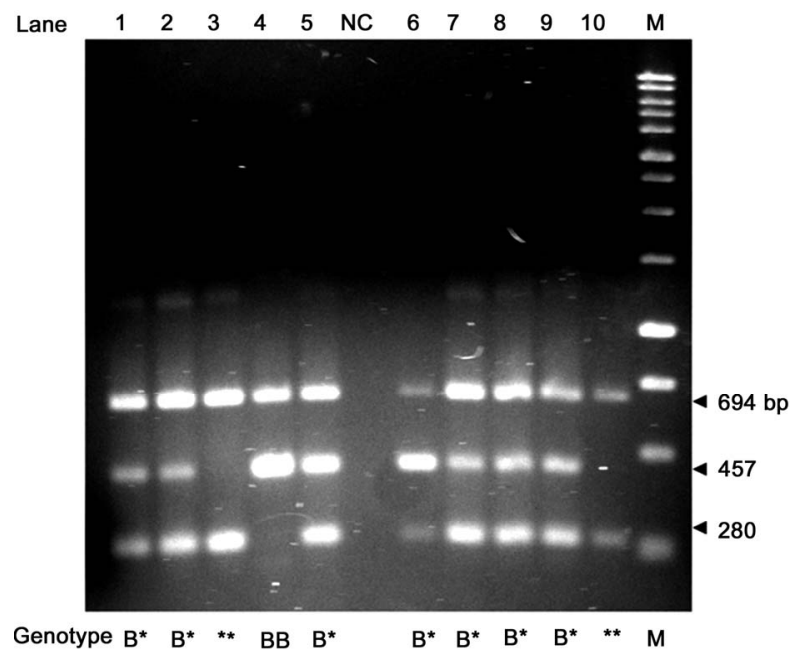

Figure 3. DNA electrophoretic patterns of the BAS-PCR amplified fragments for the $C S N 2 * B /$ non- $B$ variants in $1.5 \%$ agarose gel. $\mathrm{NC}=$ negative control. $\mathrm{M}=$ Marker BenchTop $1 \mathrm{~kb}$ DNA Ladder (Promega Corporation, Madison, WI, USA). * = non- $B$ alleles.

The SYBR ${ }^{\circledR}$ staining method was efficient and can replace conventional ethidium bromide staining. Safe staining allows to safeguard the operator's health as well as the work environment security.

Perfect agreement occurred between the genotypes inferred by the implemented techniques and all the validation samples used for both SNP.

\subsection{Routine Analyses}

The practical application of BAS-PCR on a panel of 84 Italian Brown bulls revealed the presence of $C S N 2 * B$ in 59 bulls at the heterozygous condition $\left(9 A^{1} B, 50 A^{2} B\right)$, whereas one bull was homozygous $B B$. The genotype of the remaining 24 bulls was $A^{1} A^{1}(\mathrm{n}=5)$ and $A^{1} A^{2}(\mathrm{n}=$ 19). Bulls were selected from a sample of 184 bulls partially typed for $C S N 2$. All the chosen bulls carried $C S N 2 * A^{1}$ from which $\operatorname{CSN} 2 * B$ derives. The frequency of $C S N 2 * B$ in the whole sample was 0.166 , a value slightly lower than the frequency of 0.185 found in the same breed by A. Caroli et al. [18]. The frequencies of the other alleles in the whole sample were $0.103\left(C S N 2 * A^{1}\right)$ and $0.731\left(C S N 2 * A^{2}\right)$. Casein haplotype frequencies estimated by EH software [19] are shown in Table 1, compared with data of the same breed [20,21].

It is to point out that the frequency of $C S N 2 * B$ in Italian Brown underwent a drastic reduction from 1968 to 1996, changing from 0.28 to 0.21 [22]. This decreasing trend is confirmed by A. Caroli et al. [18] and the present data, and should be carefully monitored due to the effect of $C S N 2 * B$ on technological properties of milk. In fact, casein micelles carrying $\beta$-CN $\mathrm{B}$ are more stable but more sensible to the chymosine action. Curd speed and strength are higher in $\beta$-CN B milk if compared to $\beta$ -

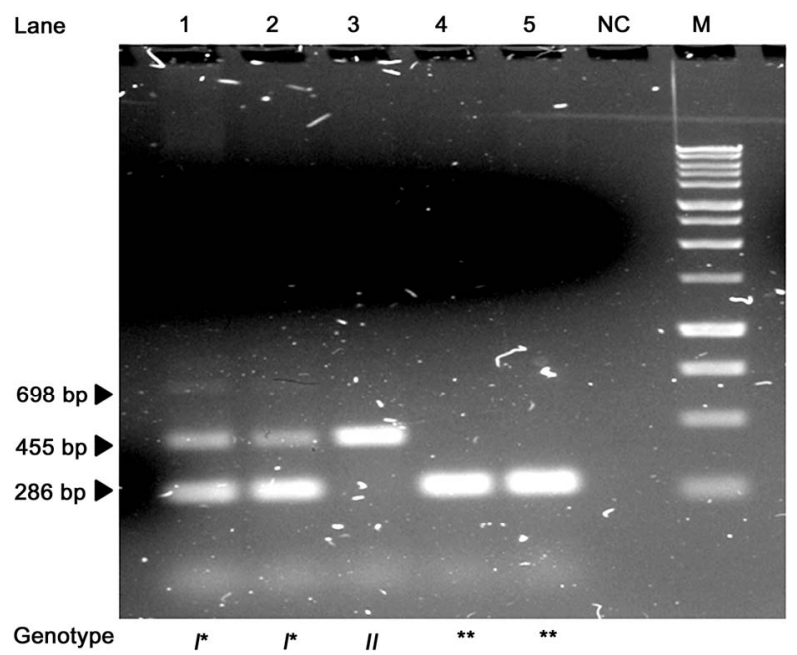

Figure 4. DNA electrophoretic patterns of the BAS-PCR amplified fragments for the CSN $2 * I /$ non- $I$ variants in $1.5 \%$ agarose gel. $\mathrm{NC}=$ negative control. $\mathrm{M}=$ Marker BenchTop $1 \mathrm{~kb}$ DNA Ladder (Promega Corporation, Madison, WI, USA). * = non- $I$ alleles.

Table 1. CSN1S1-CSN2-CSN3 haplotype frequencies in the Italian Brown in 2004 [20], 2008 [21] and 2012 (present paper). Haplotypes carrying $C S N 2 * B$ are bolded.

\begin{tabular}{cccc}
\hline Haplotype & $2004(\mathrm{n}=298)$ & $2008(\mathrm{n}=360)$ & $2012(\mathrm{n}=184)$ \\
\hline$B-A^{1}-A$ & 0.10 & 0.07 & 0.09 \\
$B-A^{1}-B$ & 0.01 & - & - \\
$B-A^{2}-A$ & 0.11 & 0.06 & 0.07 \\
$B-A^{2}-B$ & 0.50 & 0.51 & 0.60 \\
$\boldsymbol{B}-\boldsymbol{B}-\boldsymbol{A}$ & 0.11 & 0.12 & 0.12 \\
$\boldsymbol{B}-\boldsymbol{B}-\boldsymbol{B}$ & 0.07 & 0.04 & 0.04 \\
$C-A^{2}-A$ & 0.02 & - & 0.01 \\
$C-A^{2}-B$ & 0.05 & 0.10 & 0.07 \\
$F-A^{2}-B$ & 0.01 & - & - \\
\hline
\end{tabular}

casein A milk, whereas micelle size is lower, which could explain the better rennet coagulation properties of this milk [23]. One of the causes of the decreasing trend of the $C S N 2 * B$ allele may be the inclusion of the $C S N 3 * B$ variant in the selection of the Italian Brown breed. In fact in this breed the $C S N 2 * B$ variant is more frequently associated with the $C S N 3 * A$ than with the $C S N 3{ }^{*} B$, mostly associated with the $C S N 2 * A^{2}$ in this breed as also shown in previous studies [18,21].

The $C S N 2 * I$ allele was identified at the heterozygous form in 8 of the 100 Italian Friesian cows analysed by BAS-PCR. From the combined IEF typing (Figure 5), the following allele frequencies were found in the sample: $0.53\left(C S N 2 * A^{2}\right), 0.395\left(C S N 2 * A^{1}\right), 0.035(C S N 2 * B)$, $0.04(C S N 2 * I)$. Allele frequencies at the other milk protein genes, including the two main whey proteins $\beta$-lactoglobulin $(L G B)$ and $\alpha$-lactalbumin $(L A A)$, are also shown in Table 2 and compared with a previous study on Italian Friesian [18]. 


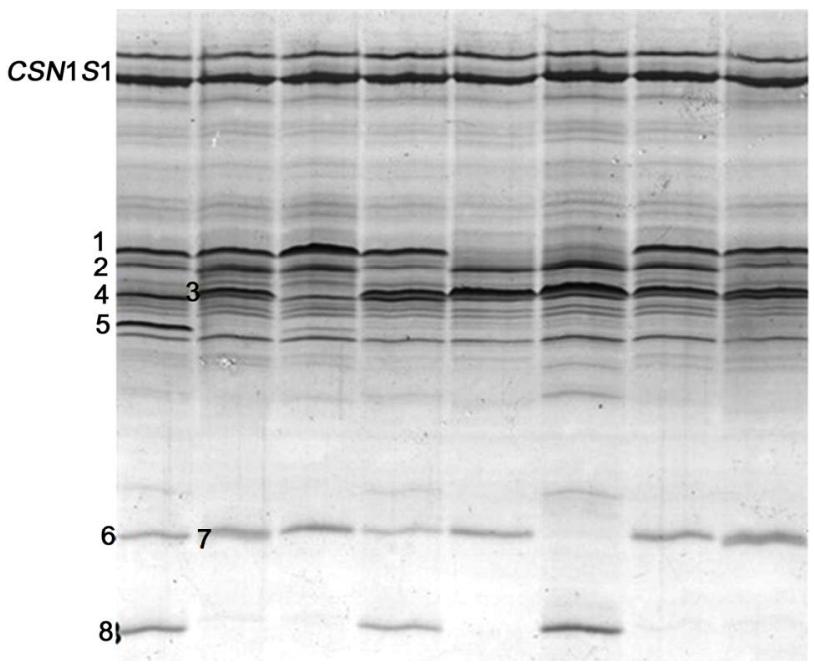

Figure 5. IEF typing of 8 individual milk Italian Friesian samples. The following milk protein variants are visible, in ascending isoelectric point: $1=C S N 2 * A^{2}(+C S N 2 * I) ; 2=L G B * A$; $3=\operatorname{CSN} 2 * A^{1} ; 4=L G B * B ; 5=\operatorname{CSN} 2 * B ; 6=C S N 3 * A ; 7=$ $C S N 3{ }^{*} E ; 8=C_{S N}{ }^{*} B$. The 2 bands of $C S N 1 S 1$ belong to the $B$ variant.

Table 2. Comparison of allele frequencies at milk proteins in Italian Friesian cows sampled in 2003 [18] and in 2012 (present paper) and typed by IEF and, in 2012, by BAS-PCR for CSN2*I.

\begin{tabular}{cccc}
\hline \multirow{2}{*}{ Gene } & \multicolumn{3}{c}{ Allele Frequency } \\
\cline { 2 - 4 }$C S N 1 S 1$ & Allele & 2003 & 2012 \\
\hline \multirow{3}{*}{$C S N 2$} & $B$ & 0.995 & 1 \\
& $C$ & 0.005 & 0 \\
& $A^{1}$ & 0.392 & 0.395 \\
& $A^{2}$ & 0.533 & 0.530 \\
& $A^{3}$ & 0.005 & 0 \\
CSN3 & $B$ & 0.070 & 0.035 \\
& $I$ & N.D. & 0.040 \\
& $A$ & 0.725 & 0.680 \\
$C S N 1 S 2$ & $B$ & 0.172 & 0.200 \\
& $E$ & 0.103 & 0.120 \\
$L A A$ & $A$ & 1 & 0.995 \\
$L G B$ & $D$ & 0 & 0.005 \\
& $B$ & 1 & 1 \\
& $A$ & 0.436 & 0.455 \\
& $B$ & 0.564 & 0.545 \\
\hline
\end{tabular}

N.D.: not determined (variant $C S N 2 * I$ was not distinguished from $A^{2}$ ).

In the last ten-year period, no substantial modification occurred at milk protein variability in Italian Friesian (Table 2). The recent development of genomic selection [24], which could affect milk protein polymorphisms strongly, increases the interest for a constant monitoring of the genetic variation of the main milk proteins in the dairy breeds.

The frequency of $C S N 2 * I$ was lower than in a previous study on Italian Friesian (frequency $=0.12$ ) [4] and in Dutch Holstein Friesian (0.14 in proven bulls, 0.27 in young bulls, 0.192 in cows) [5].

A change of the frequencies of the different milk protein variants was observed in Dutch Holstein-Friesian over a period of 16 years and might have affected the protein composition and technological properties of milk [25]. The large effect of genetic variants on protein composition also suggests that selection for specific variants or haplotypes can be a useful tool in producing milk with a desired protein composition [25].

Due to the linkage between $C S N 2 * I$ and $C S N 3 * B$ [5], the $8 C S N 2 * I$ heterozygous samples also carried $C S N 3 * B$. It is noteworthy that $C S N 2 * I$ was significantly and positively associated with protein percentage and protein yield, $\alpha_{\mathrm{S} 2}-\mathrm{CN}, \kappa-\mathrm{CN}, \mathrm{CN}$ index and yield, and negatively associated with $\alpha_{\mathrm{S}_{1}-\mathrm{CN}}, \alpha$-LA, and $\beta$-LG [5]. Only $\operatorname{CSN} 2 * I-C S N 3 * B$ haplotype was found by [5] who suggested that the association of this haplotype with protein percentage, $\kappa$-casein, $\alpha$-lactalbumin, $\beta$-lactoglobulin, and casein index might result from the effect of $C S N 3 * B$. Nevertheless, an investigation within Italian Friesian found that the positive effect on milk protein percent of the SNP related to $C S N 2 * I$ was more significant than the positive one exerted by $C S N 3 * B$ [16]. Thus, the importance of a correct identification of $C S N 2 * I$ as well as the interest to further investigate its effect on quantitative traits is evident.

In conclusion, BAS-PCR is a simple and rather cheap typing system which could be used for routinely typing of $\operatorname{CSN} 2 * B$ and $C S N 2 * I$ alleles in particular cases as the ones described in the present paper (lack of genotyping of a particular SNP at milk protein genes, genotyping of milk protein polymorphisms at the protein level when milk is available). Thus, the use of classical genotyping techniques is still actual and not completely replaceable with outsourcing high-throughput analysis.

If milk is available, the combined use of milk protein analysis by IEF and DNA analysis by BAS-PCR for CSN2*I detection is an efficient and cheap system which allows genotyping of all the most common milk protein variants. Moreover, the importance of correctly discriminating milk protein genetic variation is fundamental for a deeper comprehension of the biological mechanisms underlying milk protein composition.

\section{ACKNOWLEDGEMENTS}

This study was supported by MiPAAF (INNOVAGEN contract). We thank Dr. Salvatore Savino and Dr. Monica Raineri for their collaboration in the experimental trails.

\section{REFERENCES}

[1] Caroli, A.M., Chessa, S. and Erhardt, G.J. (2009) Milk protein genetic variation in cattle: Impact on animal breeding and human nutrition. Journal of Dairy Science, 92, 5335-5352. doi:10.3168/jds.2009-2461 
[2] Farrell Jr, H.M., Jimenez-Flores, R., Bleck, G.T., Brown, E.M., Butler, J.E., Creamer, L.K., et al. (2004) Nomenclature of the proteins of cows' milk-Sixth revision. Journal of Dairy Science, 87, 1641-1674. doi:10.3168/jds.S0022-0302(04)73319-6

[3] Formaggioni, P., Summer, A., Malacarne, M. and Mariani, P. (1999) Milk protein polymorphism: Detection and diffusion of the genetic variants in Bos genus. Annali della Facoltà di Medicina Veterinaria Università di Parma, 29, 127-165.

[4] Jann, O., Ceriotti, G., Caroli, A. and Erhardt, G. (2002) A new variant in exon VII of bovine $\beta$-casein gene (CSN2) and its distribution among European cattle breeds. Journal of Animal Breeding and Genetics, 119, 65-68. doi:10.1046/j.1439-0388.2002.00318.x

[5] Visker, M.H.P.W., Dibbits, B.W., Kinders S.M., van Valenberg, H.J.F., van Arendonk, J.A.M. and Bovenhuis, H. (2010) Association of bovine $\beta$-casein protein variant I with milk production and milk protein composition. Animal Genetics, 42, 212-218. doi:10.1111/j.1365-2052.2010.02106.x

[6] Aschaffenburg, R. (1966) Modified procedure of starch gel electrophoresis for $\beta$-casein phenotyping. Journal of Dairy Science, 49, 1284. doi:10.3168/jds.S0022-0302(66)88073-6

[7] Krause, I., Buchberger, J., Weis, G. and Klostermeyer, H. (1988) Screening methods for genetic variants of milk proteins. In: Barth, C.A. and Schlimme, E. Eds., Milk Proteins: Nutritional, Clinical, Functional and Technological Aspects, Steinkopff Verlag, Darmstadt, 171-173.

[8] Bech, A.-M. and Kristiansen, K.R. (1990) Milk protein polymorphism in Danish dairy cattle and the influence of genetic variants on milk yield. Journal of Dairy Research, 57, 53-62. doi:10.1017/S0022029900026601

[9] Erhardt, G., Juszczak, J., Panicke, L. and Krick-Saleck, H. (1998) Genetic polymorphism of milk proteins in Polish Red Cattle: A new genetic variant of $\beta$-lactoglobulin. Journal of Animal Breeding and Genetics, 115, 63-71. doi:10.1111/j.1439-0388.1998.tb00328.x

[10] Bonfatti, V., Grigoletto, L., Cecchinato, A., Gallo, L. and Carnier, P. (2008) Validation of a new reversed-phase high-performance liquid chromatography method for separation and quantification of bovine milk protein genetic variants. Journal of Chromatography A, 1195, 101-106. doi:10.1016/j.chroma.2008.04.075

[11] Keating, A.F., Smith, T.J., Ross, R.P. and Cairns, M.T. (2006) A single nucleotide polymorphism in the bovine beta-casein promoter region across different bovine breeds. Journal of Dairy Research, 73, 193-196. doi:10.1017/S0022029905001615

[12] Damiani, G., Pilla, F., Leone, P. and Cacciò, S. (1992) Direct sequencing and bidirectional allele specific polymerase chain reaction of the bovine beta-casein B variant. Animal Genetics, 23, 561-565. doi:10.1111/j.1365-2052.1992.tb00180.x

[13] Lien, S., Alestrom, P., Hlungland, H. and Rogne, S. (1992) Detection of multiple beta-casein (CASB) alleles by am- plification created restriction sites (ACRS). Animal Genetics, 23, 333-338. doi:10.1111/j.1365-2052.1992.tb00155.x

[14] Barroso, A., Dunner, S. and Canon, J. (1999) A multiplex PCR-SSCP test to genotype bovine beta-casein alleles $\mathrm{A}^{1}$, $\mathrm{A}^{2}, \mathrm{~A}^{3}, \mathrm{~B}$, and C. Animal Genetics, 30, 322-323. doi:10.1046/j.1365-2052.1999.00445-6.x

[15] Chessa, S., Chiatti, F., Ceriotti, G., Caroli, A., Consolandi, C., Pagnacco, G. and Castiglioni, B. (2007) Development of a SNP genotyping microarray platform for the identification of bovine milk protein genetic polymorphisms. Journal of Dairy Science, 90, 451-464. doi:10.3168/jds.S0022-0302(07)72647-4

[16] Pariset, L., Caroli, A., Chessa, S., Fontanesi, L., Russo, V., Bagnato, A., et al. (2009) Assessment of 29 candidate genes for milk traits in Italian dairy cattle. Italian Journal of Animal Science, 8, 226.

[17] Rozen, S. and Skaletsky, H.J. (2000) Primer3 on the WWW for general users and for biologist programmers. In: Krawetz, S. and Misener, S., Eds., Bioinformatics Methods and Protocols: Methods in Molecular Biology, Humana Press, Totowa, 365-386.

[18] Caroli, A., Chessa, S., Vivona, G., Bolla, P. and Pagnacco, G. (2003) Analysis of milk protein polymorphisms and casein haplotypes in Italian Friesian, Italian Brown Swiss and Reggiana cattle. Book of Abstract of the 54th Annual Meeting of the European Association for Animal Production, Roma, 31 August-3 September 2003, 97.

[19] Xie, X. and Ott, J. (1993) Testing linkage disequilibrium between a disease gene and marker loci. American Journal of Human Genetics, 53, 1107.

[20] Boettcher, P.J., Caroli, A., Stella, A., Chessa, S., Budelli, E., Canavesi, F., et al. (2004) Effects of casein haplotypes on production traits in Italian Holstein and Brown Cattle. Journal of Dairy Science, 87, 4311-4317. doi:10.3168/jds.S0022-0302(04)73576-6

[21] Chessa, S., Rignanese, D., Conte, G., Severgnini, M., Ceriotti, G., Caroli, A., Pagnacco, G. and Castiglioni, B. (2008) Application of a microarray technology to SNPs detection within genes involved in milk production. Chromosome Research, 16, 1041-1042.

[22] Mariani, P. (1997) Contenuto di caseina, varianti genetiche ed attitudine tecnologico-casearia del latte delle vacche di razza bruna nella produzione del formaggio grana. $L a$ razza Bruna italiana, 2, 8-14.

[23] Mariani, P. (1999) Polimorfismo delle proteine ed attitudine tecnologico-casearia del latte. La Razza Bruna Italiana, 1, 1-7.

[24] Hayes, B.J., Bowman, P.J., Chamberlain, A.J. and Goddard, M.E. (2009) Invited review: Genomic selection in dairy cattle: Progress and challenges. Journal of. Dairy Science, 92, 433-443. doi:10.3168/jds.2008-1646

[25] Heck, J.M.L., Schennink, A., van Valenberg, H.J.F., Bovenhuis, H., Visker, M.H.P.W., van Arendonk, J.A.M., et al. (2009) Effects of milk protein variants on the protein composition of bovine milk. Journal of Dairy Science, 92, 1192-1202. doi:10.3168/jds.2008-1208 